\title{
TEORIJSKO-FILOZOFSKO UTEMELJENJE KNJIŽNIČNE I INFORMACIJSKE ZNANOSTI \\ U FILOZOFIJI INFORMACIJE
}

\author{
THE THEORETICAL-PHILOSOPHICAL \\ FOUNDATION OF LIBRARY AND INFORMATION SCIENCE \\ IN THE PHILOSOPHY OF INFORMATION
}

\author{
Josip Ferlindeš ${ }^{1}$ \\ Katolički bogoslovni fakultet \\ jferlindes@gmail.com \\ Sonja Špiranec \\ Odsjek za informacijske znanosti \\ Filozofski fakultet u Zagrebu \\ sspiran@ffzg.hr
}

\author{
UDK / UDC [02: 001.102]:1 \\ Pregledni rad / Review paper \\ Primljeno / Received: 23. 1. 2018. \\ Prihvaćeno / Accepted: 24. 4. 2018.
}

\section{Sažetak}

Cilj. Cilj je rada prikazati te provesti kritičku analizu konceptualnog opsega i potencijalnog dosega filozofije informacije Luciana Floridija kao pokušaja teorijsko-filozofskog utemeljenja knjižnične i informacijske znanosti. Filozofska i intelektualna utemeljenost znanstvene discipline ključni je čimbenik njezine znanstvene snage, statusa i identiteta, a upravo za knjižničnu i informacijsku znanost moguće je iznijeti konstataciju da konsenzus o filozofskim premisama te discipline ne postoji, što donosi brojne posljedice poput krize identiteta ili propitivanja njezine znanstvene snage.

1 Članak je dopunjena i izmijenjena inačica diplomskoga rada autora Josipa Ferlindeša, napisana pod mentorskim vodstvom Sonje Špiranec te obranjena 2017. godine na Odsjeku za informacijske i komunikacijske znanosti Filozofskog fakulteta Sveučilišta u Zagrebu.

Vjesnik bibliotekara Hrvatske 61, 1(2018), 37-56

ISSN 0507-1925

(C) VBH 2018. 
Pristup/metodologija/dizajn. Primjenom kvalitativnog pristupa analize literature ispituju se temeljni koncepti Floridijevih radova koji se suprotstavljaju ranijim filozofskim pristupima u knjižničnoj i informacijskoj znanosti te propituju s afirmativnih i kritičkih stajališta.

Rezultati. Obrazloženo je zašto raniji pokušaji filozofskog utemeljenja discipline, poput Popperove teorije o tri svijeta i socijalne epistemologije, ne mogu pružiti zadovoljavajuće teorijsko utemeljenje knjižničnoj i informacijskoj znanosti. Na temelju analize kritičkog i afirmativnog pristupa ideji o knjižničnoj i informacijskoj znanosti kao primijenjenoj filozofiji informacije i ključnih Floridijevih koncepata koji su ekvivalentni problemskim težištima koje je iznjedrilo suvremeno kompleksno informacijsko okruženje, donosi se zaključak o filozofiji informacije kao produktivnom uporištu za teorijsko utemeljenje knjižnične i informacijske znanosti.

Originalnost/vrijednost. Rad pozicionira knjižničnu i informacijsku znanost u konceptualni prostor filozofije informacije. Pritom polazi od konstatacije o krizi identiteta $\mathrm{u}$ informacijskim disciplinama i prepoznaje upravo filozofiju informacije kao uporište teorijsko-filozofskog utemeljenja koje je neophodno u prevladavanju krize. Rad ujedno popunjava relativnu prazninu u hrvatskoj literaturi u kojoj Floridijevi koncepti i pogled na knjižničnu i informacijsku znanost nisu detaljnije obrađivani.

Ključne riječi: filozofija informacije, informacijske znanosti, knjižnična i informacijska znanost, socijalna epistemologija

\section{Abstract}

Purpose. The purpose of the paper is to present and carry out a critical analysis of the conceptual scope and range of Luciano Floridi's Philosophy of Information as a philosophical foundation of Library and Information Science (LIS). The philosophical and intellectual foundations of a scientific discipline are the key to its scientific power, status, and identity. In LIS there is no common consensus on the philosophical premises of this discipline, which consequently deepens its identity crisis and brings into question whether LIS is a scientific discipline at all.

Approach/methodology/design. By using qualitative literature analysis, the key concepts in Floridi's writings are analysed and contrasted, first with earlier philosophical approaches to LIS, and then (re)examined by applying an affirmative and critical lens.

Findings. The authors explicate why earlier attempts in establishing philosophical foundations of the field, like Popper's three worlds schema and social epistemology, cannot provide a satisfactory theoretical foundation for LIS. Based on the analysis of the critical and affirmative approach to the idea of Library and Information Science as an applied philosophy of information and the key Floridian concepts that reflect problems generated by contemporary complex information environments, the authors conclude 
that the philosophy of information provides an adequate and productive basis for a theoretical foundation of LIS.

Originality/value. The paper positions LIS into the conceptual space of Floridi's Philosophy of Information. Expanding this position, the authors take the identity crisis in information disciplines as a starting point and the potential of the Philosophy of Information as a foundation necessary to overcome the crisis. The paper also addresses the research gap in Croatian scientific literature in which, up to now, Floridi's concepts and perspectives on LIS have not been discussed in detail.

Keywords: information sciences, library and information science, philosophy of information, social epistemology

\section{Uvod}

Razmatranja o intelektualnim polazištima i perspektivama obilježila su razvoj knjižničarstva, a potom i knjižnične i informacijske znanosti, od samih početaka, a ni danas promišljanja o teorijskom utemeljenju ne gube na intenzitetu. Horizont propitivanja kreće se od tumačenja knjižničarstva u okviru šireg interdisciplinarnog polja informacijskih znanosti do eksplicitnog ili suptilnog osporavanja njegova znanstvenog statusa. Implicitno osporavanje znanstvenog statusa moguće je iščitati i iz promjena u akademskoj nomenklaturi, gdje dolazi do brisanja izraza knjižničarstvo u nazivu brojnih knjižničarskih (LIS, engl. Library and Information Science) studijskih programa, koji su preimenovani u informacijske škole ili I-škole ${ }^{2,3}$ (engl. $i S c h o o l$ ili I-school). Iako su razlozi tih promjena brojni i pragmatične su prirode, neki autori drže da su one ujedno i rezultat prevelike praktične usredotočenosti i slabog znanstvenog statusa knjižničarstva, pa bi preimenovanje trebalo osigurati iskazivanje istraživačkog karaktera programa i usmjerenost na teorije. ${ }^{4}$

Rasprave koje eksplicitnije propituju ili dovode u pitanje znanstveni status knjižnične i informacijske znanosti upućuju na njezinu preveliku praktičnu usredotočenost $^{5}$ ili na nedostatak teorija kao temeljnih zajedničkih referentnih točaka

2 Hjørland, B. Information science and its core concepts: levels of disagreement. // Theories of information, communication and knowledge / ed. by Fidelia Ibekwe-SanJuan and Thomas M. Dousa. Netherlands : Springer, 2014. Str. 210.

3 Hjorland drži da naziv informacijska škola signalizira kako kurikulum u takvim ustanovama nije baziran na jednoj znanstvenoj disciplini, nego ga čini skupina različitih predmeta relevantnih za školovanje stručnjaka u informacijskom području.

4 Usp. Chow, A. S.; T. L. Shaw; D. Gwynn; D. Martensen; M. Howard. Changing times and requirements: implications for LIS Education. // LIBRES: Library \& Information Science Research Electronic Journal 21, 1(2011). [citirano: 2018-04-15]. Dostupno na: https://libres.uncg.edu/ ir/uncg/f/A_Chow_Changing_2011.pdf; Dillon, A. What it means to be an iSchool. // Journal of Education for Library and Information Science 53, 4(2012), 267-273.

5 Hjørland, B. Nav. dj., str. 208. 
discipline. U tom kontekstu mogu se pronaći brojni osvrti o ateoretičnosti knjižnične i informacijske znanosti ${ }^{6}$, prekomjernom posuđivanju teorije drugih područja umjesto razvoja vlastitih ${ }^{7}$, opaske o teorijskoj getoizaciji koja je dovela do toga da više ne možemo govoriti o interdisciplinarnom, nego izvandisciplinarnom statusu $^{8}$ te kritika teorijskih improvizacija ${ }^{9}$ i teorijskog promiskuiteta ${ }^{10}$ koji karakteriziraju ovo polje.

Teorijska utemeljenost neke discipline izravno utječe i na formiranje profesionalnog identiteta i percepcije profesije u zajednici, a teorijska raspršenost u knjižničnoj i informacijskoj znanosti nesumnjivo je jedan od čimbenika koji su doveli do krize identiteta u tome polju. ${ }^{11}$ Ona se primjerice iskazuje u nerazumijevanju fokusa rada i djelovanja knjižnica koje moraju opravdavati i „dokazivati“ potrebu svojega postojanja, a sa sličnim se diskursom susreću i knjižničari i informacijski stručnjaci, znanstvenici ili studenti informacijskih znanosti čiji su predmet i opseg rada, istraživanja ili studija često nejasni široj zajednici i društvu. E. Ford drži da je glavni uzrok takva nerazumijevanja, a time i krize identiteta, nepostojanje filozofije polja koja bi bila okosnica za definiranje svrhe i ciljeva, koncipiranje budućeg razvoja, ali i podloga za donošenje odluka u praksi. ${ }^{12}$ Bez teorijsko-filozofskog uporišta opstanak knjižnične i informacijske znanosti kao znanstvene, pa čak i akademske discipline, vrlo je upitan, a produbljivanje krize identiteta i deprofesionalizacija postaju neizbježni.

\footnotetext{
6 Usp. Jarvelin, K.; P. Vakkari. Content analysis of research articles in library and information science. // Library and Information Science Research 12, 4(1990), 395-421.; Pettigrew, K. E.; L. Mckechnie. The use of theory in information science research. // Journal of the Association for Information Science and Technology 52, 1(2001), 62-73.

7 Zwadlo, J. We don't need philosophy of library and information science: we're confused enough already. // The Library Quarterly 67, 2(1997), str. 105.

8 Pierce, S. Dead Germans and the theory of librarianship. // American Libraries 23, 8(1992), 641-643.

9 Feather, J. LIS research in the United Kingdom: reflections and prospects. // Journal of Librarianship and Information Science 41, 3(2010), 173-181.

10 Cronin, B. The waxing and waning of a field: reflections on information studies education. // Information Research 17, 3(2012), paper 529. [citirano: 2018-04-15]. Dostupno na: http://InformationR.net/ir/17-3/paper529.html.

11 Usp. Dillon, A. Keynote address: library and information science as a research domain: problems and prospects. // Information Research 12, 4(2007), 1-8.; Aparac-Jelušić, T., F. Ibekwe-SanJuan; I. Huvila;, L. Ma; V.O. R. Jimenez; J. Warner. Crossing the boundaries in information science: perspectives on interdisciplinarity. // Proceedings of the Association for Information Science and Technology 50, 1(2013), 1-3.; Lorenz, M.; A. Novaka. The i-school phenomenon : history and present situation. // Revue of Librarianship 25, 2(2014), 58-82. [citirano:2017-12-20]. Dostupno na: http://full.nkp.cz/nkkr/knihovna142_supp1/142supp058.htm.

12 Ford, E. What do we do and why do we do it? // In the library with the Lead Pipe, (2012). [citirano: 2017-12-20]. Dostupno na: http://inthelibrarywiththeleadpipe.org/2012/what-do-wedo-and-why-do-we-do-it/.
} 
Poticajno, ali nedovoljno razmotreno, polazište za neophodno teorijsko-filozofsko uporište knjižnične i informacijske znanosti pojavilo se prije petnaestak godina u filozofiji informacije Luciana Floridija. Neki teoretičari informacijskih disciplina najčešće su odgovore tražili u Popperovoj teoriji o tri svijeta i socijalnoj epistemologiji, no imajući u vidu nova problemska težišta koja je iznjedrilo suvremeno kompleksno informacijsko okruženje, nameće se misao da snažniji potencijal pruža filozofija informacije, što ju čini važnom sastavnicom u teorijskom promišljanju o utemeljenju knjižnične i informacijske znanosti kao znanstvene discipline.

\section{Ranija teorijsko-filozofska uporišta knjižnične i informacijske znanosti}

\subsection{Popperova teorija o tri svijeta}

Određeni teoretičari koji su dali svoj doprinos u traženju adekvatnog teorijsko-filozofskog uporišta područja knjižnične i informacijske znanosti često su pomoć tražili u radovima filozofa i sociologa koji su se bavili propitivanjem znanja. Tako D. Bawden i L. Robinson ističu kako su prije filozofije informacije postojale samo dvije relevantne filozofije koje su mogle poslužiti kao teorijsko-filozofsko uporište knjižničnoj i informacijskoj znanosti, a to su Popperova teorija o tri svijeta i socijalna epistemologija. Međutim one nisu bile usmjerene prema knjižničnoj i informacijskoj znanosti (engl. LIS) kao jedinstvenoj disciplini, već se Popperova teorija više odnosila na informacijske znanosti, a socijalna epistemologija na knjižničarstvo. ${ }^{13}$

K. Popper svoju je teoriju predložio u svrhu tumačenja rasta znanja, osobito znanstvenog znanja, te razumijevanja interakcije između osobnog (subjektivnog) i komunikabilnog (objektivnog) znanja. ${ }^{14}$ Prema toj teoriji postoje tri različita svijeta. Svijet 1 jest fizički svijet ili svijet fizičkih stanja, svijet koji opisuju fizika, astronomija, kemija i biologija. Svijet 2 jest svijet svijesti ili duhovnih stanja i njega čine naši osobni, subjektivni doživljaji, naše nade, ciljevi, patnje i radosti, naše misli u subjektivnom smislu. Svijet 3 jest svijet ideja u objektivnom smislu. To je svijet teorija po sebi i njihovih logičkih veza, on je rezultat našeg misaonog rada, svijet jezično ili pismeno formuliranih misli te svijet tehnike i umjetnosti. ${ }^{15}$

\footnotetext{
13 Bawden, D.; L. Robinson. Curating the infosphere: Luciano Floridi's philosophy of information as the foundation for library and information science. // Journal of Documentation 73, 5(2017), str. 6.

14 Bawden, D. The three worlds of health information. // Journal of Information Science 28, 1(2002), 51-62.

15 Popper, K. R. U potrazi za boljim svijetom: predavanja i napisi iz trideset godina. Zagreb : KruZak, 1997. Str. 114; 164.
} 
U pokušaju da utemelji informacijske znanosti na filozofskim postavkama Popperove teorije ili, preciznije, ontologije, najdalje je otišao B. C. Brookes ${ }^{16}$, koji je smatrao da bi se znanost o informacijama kao znanstvena disciplina trebala fokusirati upravo na istraživanje i organizaciju Popperova svijeta 3 , svijeta objektivnog znanja, te na proučavanje međuodnosa svijeta 2 i svijeta 3 . Time informacijska znanost može obrazložiti pravo na vlastitu teoriju i vlastite probleme, a teoretičari informacijske znanosti mogu, koristeći se koncepcijom svijeta 3 kao logičkim načelom, prvi put prikazati svoju djelatnost na neki drugi, a ne na čisto iskustven način. Prema Bawdenu, ontologija koju je Popper zastupao bila je široko prihvaćena i intuitivno razumljiva u informacijskim znanostima jer prepoznaje dvije ,komponente" bilo kojeg informacijskog sustava u najširem smislu: fizičke objekte/ nositelje informacije i emocijama vođene korisnike informacija. Svijet 3 nešto je apstraktniji, ali je načelno izjednačiv s idejom ,sadržaja“ fizičke informacije. ${ }^{17}$

Zanimljivo je napomenuti da Floridi ističe upravo Popperovu koncepciju svijeta 3 kao primjer evolucije filozofije informacije u razdoblju prije digitalne revolucije te da je i sam bio pod utjecajem Popperove ideje znanja. Dakle dok Popperova teorija sama po sebi ne osigurava dovoljno dobro teorijsko uporište za knjižničnu i informacijsku znanost zbog nekih nedostataka i nedorečenosti raspravljenih u literaturi $^{18}$, jasno je da je imala značajan utjecaj na postavljanje temelja za Floridijevu filozofiju informacije kakvu danas poznajemo. ${ }^{19}$

\subsection{Socijalna epistemologija}

Nakon što su sredinom dvadesetog stoljeća M. Egan i J. Shera objavili svoje znanstvene radove o teoriji knjižničarstva, pojedini znanstvenici koji su se bavili proučavanjem knjižnične i informacijske znanosti zagovarali su ideju o socijalnoj epistemologiji kao grani unutar koje će ta disciplina pronaći svoje teorijsko utemeljenje. ${ }^{20}$

Kao što navodi T. Aparac-Gazivoda, socijalna epistemologija posebna je grana epistemologije koja proučava socijalnu dimenziju znanja i informacija. To je disciplina koja se bavi načinima na koje društvo kao cjelina postiže perceptivan odnos prema ukupnom okruženju i upravo je u njoj te u općoj semantici J. Shera pronašao ishodišne točke kako bi razvio tu svoju teoriju. Socijalna epistemologija

16 Usp. Brookes, B.C. The foundations of information science: Part I. : Philosophical aspects. // Journal of Information Science 2, 3-4(1980), 125-133.

17 Bawden, D. Nav. dj., str. 52.

18 Usp. Tuđman, M. Teorija informacijske znanosti. Zagreb : Hrvatska sveučilišna naklada: Nacionalna i sveučilišna knjižnica, 2014. Str. 184; Bawden, D. Nav. dj., str. 53-54.

19 Bawden, D.; L. Robinson. Nav. dj., str. 6.

20 Fyffe, R. The value of information : normativity, epistemology, and LIS in Luciano Floridi. // portal: Libraries and the Academy 15, 2(2015), str. 269. 
ponudila je teorijski okvir za interdisciplinarna istraživanja problema u procesima stvaranja, bilježenja, prijenosa i korištenja znanja od strane pojedinca i društva, u kojima je knjižničarstvo tek jedna disciplina koja može pridonijeti sagledavanju tih problema. ${ }^{21}$

Birger Hjørland naslanja se na polazišta socijalne epistemologije naglašavajući kognitivnu (spoznajnu) perspektivu koja se odnosi na interpretaciju, organizaciju i pretraživost tekstova od strane korisnika, ali također smatra da je sve, od alata, preko informacijskih struktura i potreba, pa sve do kriterija relevantnosti, uvjetovano i oblikovano određenim društvenim diskursom, odnosno unutar diskursnih zajednica u kojima se odvijaju zadani komunikacijski procesi. ${ }^{22}$

Među prvima koji su analitički doveli u pitanje filozofsku utemeljenost knjižnične i informacijske znanosti u socijalnoj epistemologiji bio je upravo Floridi, naglašavajući da socijalna epistemologija zbog preskriptivnosti ${ }^{23}$ nikako ne može biti intelektualna osnova te discipline, koja bi trebala biti postavljena normativno, a ne epistemološki-preskriptivno.

Floridijevu kritiku socijalne epistemologije detaljnije razrađuje R. Fyffe, koji naglašava kako je Sherin koncept socijalne epistemologije deskriptivan i analitički budući da opisuje način na koji se znanje prenosi te analizira koji čimbenici utječu na prenošenje tog znanja, no ne objašnjava normativne dimenzije knjižničarstva. Prema takvu tumačenju knjižničarstvo nije odgovorno za opravdavanje i dokazivanje tvrdnji o znanju, već dokumentira dokaze i pomaže korisnicima u tumačenju i vrednovanju izvora i dokaza. ${ }^{24}$ Kako bismo lakše shvatili odnos između socijalne epistemologije te knjižnične i informacijske znanosti, Floridi predlaže da ih ne gledamo hijerarhijski, kao jednu granu podložnu drugoj, već kao dvije zasebne grane filozofije informacije. Knjižnična i informacijska znanost povezana je i sa socijalnom epistemologijom i s filozofijom informacije. No socijalna epistemologija ne može pružiti zadovoljavajuće teorijsko utemeljenje jer „govoreći obiteljskim rječnikom, socijalnu epistemologiju na jednoj i knjižničnu i informacijsku znanost na drugoj strani trebamo shvatiti kao brata i sestru koji dijele zajedničkog roditelja, a to je filozofija informacije“ .25

\footnotetext{
21 Aparac-Gazivoda, T. Teorijske osnove knjižnične znanosti. Zagreb: Zavod za informacijske studije, 1993. Str. 129-131.

22 Hjørland, B. Epistemology and the socio-cognitive perspective in information science. // Journal of the American Society for Information Science and Technology 53, 4(2002), str. 268; 258.

23 Obilježje preskriptivnosti epistemologije Floridi slikovito opisuje na sljedećem primjeru: cilj epistemologije nije utvrditi što netko vjeruje o zvijezdama, nego što bi netko trebao vjerovati o zvijezdama i što je opravdano vjerovati o zvijezdama, što je u raskoraku s djelovanjem knjižnica i informacijskih ustanova.

24 Fyffe, R. Nav. dj., str. 270.

25 Floridi, L. On defining library and information science as applied philosophy of information. // Social Epistemology 16, 1(2002), str. 37-38.
} 


\section{Filozofija informacije kao teorijsko-filozofsko uporište knjižnične i informacijske znanosti}

Prije prikaza Floridijeve filozofije informacije potrebno je naglasiti da njegovo nastojanje cjelovitog filozofskog zasnivanja područja knjižnične i informacijske znanosti nije bilo prvi pokušaj takve vrste; u tom kontekstu nezaobilazno je spomenuti opsežan rad i djelo R. Capurra, koji se u svojim promišljanjima i radovima usredotočio na povijesne i suvremene dimenzije središnjeg koncepta discipline - informaciju - te je ponudio doprinos u konceptualnom pozicioniranju i definiranju discipline koja ju proučava, polazeći pritom od hermeneutičko-retoričkog tumačenja informacijske znanosti kao discipline usredotočene na ljude, a ne na tehnologiju ili objektivnu konceptualizaciju informacije. ${ }^{26}$ Floridijevo djelo u smislu cjelovitosti i ambicije često je uspoređivano upravo s Capurrovim radom, iako je zamjetno da se Floridijev opus oslanja na analitički vokabular u promišljanju ne samo informacije nego i informacijskog društva i utjecaja tehnologije na društvo, te je tako ponudio model koji je izravno primjenjiv u knjižničnoj i informacijskoj znanosti. ${ }^{27}$

\subsection{Filozofija informacije Luciana Floridija}

Promišljajući o općoj definiciji informacije, Floridi ${ }^{28}$ dolazi do zaključka kako ona uzima u obzir i tzv. pogrešne informacije koje po njemu uopće nisu informacije. Stoga on predlaže novu, modificiranu definiciju, koja bi obuhvaćala istinitost kao jedan od temeljnih postulata, pa tako za njega informacija predstavlja „dobro organiziran, smislen i istinit podatak“ ${ }^{29}$ U Floridijevoj filozofiji informacije semantika ima jednu od ključnih uloga, gdje jezik postaje posrednik između stvari i spoznaje jer se kroz njega izgovorena riječ imenuje kao informacija.

U svome članku iz 2002. godine pod nazivom What is the philosophy of information Floridi je prvi put predstavio svoju definiciju filozofije informacije. Prema njemu postoje barem tri razloga zbog kojih je filozofija informacije zrela da postane samostalna disciplina. Prvo, ona predstavlja jedno novo i autonomno (samostalno) područje istraživanja; drugo, osigurava inovativan pristup starim i

\footnotetext{
26 Capurro, R. What is information science for? : a philosophical reflection. // Conceptions of library and information science : historical, empirical and theoretical perspectives / ed. by Pertti Vakkari and Blaise Cronin. London : Taylor Graham, 1992. Str. 82-96.; Horić, A. Informacija povijest jednog pojma: o Capurrovom razumijevanju pojma informacije. // Vjesnik bibliotekara Hrvatske 50, 1/2(2007), 96-106.

27 Bawden, D.; L. Robinson. Super-science, fundamental dimension, way of being : library and information science in an age of messages. // Information Cultures in the Digital Age / ed. by M. Kelly, J. Bielby. Wiesbaden : Springer VS, 2016. Str. 31-43.

28 Usp. Floridi, L. The philosophy of information. Oxford : Oxford University Press, 2011. Str. 80-107.

29 Isto, str. 106.
} 
novim filozofskim temama i treće, može stati uz bok ostalim granama filozofije, nudeći im sustavan prikaz konceptualnih temelja svijeta informacija i informacijskog društva. ${ }^{30}$

Definirajući filozofiju informacije Floridi navodi da je to „područje filozofije koje se bavi (a) kritičkim istraživanjem konceptualne naravi i temeljnih načela informacije uključujući njezinu dinamiku, korištenje i znanost te (b) razradom i primjenom informacijsko-teorijskih i računalnih metodologija u rješavanju filozofskih problema".31

U nastavku Floridijeva rada slijedi analiza te definicije, u kojoj stoji da se prvi dio definicije odnosi na filozofiju informacije kao novog područja u filozofiji koje bi trebalo dati odgovor na pitanje što je to informacija, odnosno koja je njezina bit. Cilj filozofije informacije nije osmisliti neku jedinstvenu teoriju, kao što je npr. kvantitativna teorija, već obuhvatiti što više postojećih teorija koje analiziraju, vrednuju i objašnjavaju različite principe informacije. Drugi dio definicije ukazuje na to da filozofija informacije nije samo neko novo područje koje treba istražiti, već ona pruža i sasvim novu metodologiju. Ona bi trebala osigurati teorijski okvir unutar kojega će se naći ostala specijalizirana područja koja već postoje i aktivno sudjeluju u analizi informacijskog društva, kao što su naprimjer informacijska etika, filozofija umjetnog života, filozofija računalstva, razne teorije informacijskih sustava itd. Nezaobilazan utjecaj informacijskog društva na čovjeka otvorio je neka nova pitanja i postavio intelektualne zahtjeve s kojima se filozofija odlučila uhvatiti ukoštac. Zato filozofija informacije pokušava proširiti granice filozofskog istraživanja i promišljanja objedinjujući na jednom mjestu već postojeće teme i omogućavajući nekim drugim temama, koje do sada nisu bile prepoznate kao značajne, da i one dobiju svoje mjesto u analizi. ${ }^{32}$

Promišljajući o budućnosti filozofije informacije Floridi njezin temeljni gradivni element - informaciju - predstavlja kao sam bitak i sastavni dio svega što nas okružuje. Zbog toga on predviđa da bi s daljnjim razvojem informacijskog društva i filozofija informacije jednoga dana mogla dosegnuti razinu Aristotelove prve filozofije (philosophia prima). ${ }^{33}$

Budući da je kod Aristotela philosophia prima označavala „znanstveno istraživanje prvih počela i uzroka“"34, slijedom toga i filozofija informacije jednoga bi dana trebala zauzeti „temeljni položaj u srcu suvremene filozofije“. .35

30 Floridi, L. What is the philosophy of information? // Metaphilosophy 33, 1-2(2002), str. 123.

31 Isto, str. 137.

32 Isto, str. 138-139.

33 Isto, str. 140-142.

34 Aristotel. Metafizika. Zagreb : Globus, 1988. Str. 8.

35 Furner, J. Philosophy and information studies. // Annual Review of Information Science and Technology 44 (2008), str. 172. 
Floridi je svjestan da je filozofija informacije mlada disciplina koja se još razvija i obuhvaća niz otvorenih pitanja ${ }^{36}$ koja treba riješiti, no on joj predviđa svijetlu budućnost jer za njega ona predstavlja „,najuzbudljivije i najplodnije područje filozofskog istraživanja danas". ${ }^{37}$

W. Hofkirchner sažima Floridijeva promišljanja u 3 ključne točke ${ }^{38}$ koje prema našem razumijevanju ujedno čine okosnicu za neposredno filozofsko utemeljenje knjižnične i informacijske znanosti:

1. četvrta revolucija u povijesti ljudske samospoznaje koja je potaknuta informacijskom tehnologijom stvarnost pretvara u tzv. infosferu u kojoj ljudi postaju informacijski agenti te više nemaju povlašteno mjesto u kreiranju i procesiranju informacija

2. neizbježnost i stalnost informacijskih interakcija u infosferi nameće potrebu upravljanja informacijskim procesima, semantičkim okruženjem, tj. životnim ciklusom informacija

3. upravljanje informacijskim procesima zahtijeva promišljanja na makroetičkoj razini.

Virtualna stvarnost koja nas okružuje zahtijeva novi filozofski pristup objašnjenju nove stvarnosti i našeg odnosa prema toj unaprijeđenoj stvarnosti. Iz tog nastojanja da se pronikne u odgovore na neka metafizička pitanja (npr. što je istina, što je podatak, što je informacija, što je relevantnost itd.) te izrade potrebne ontologije za iskazivanje nove stvarnosti i relacija između njezinih elemenata proizlazi teza da bi knjižnična i informacijska znanost upravo u filozofiji informacije mogla pronaći najprikladnije teorijsko uporište.

\subsection{Knjižnična i informacijska znanost kao primijenjena filozofija in- formacije}

Unatoč velikom broju radova i analiza posvećenih definiranju knjižnične i informacijske znanosti kao znanstvene discipline u kojoj je konstatirana manjkava teorijska utemeljenost, malo je pokušaja preciznog određenja i predlaganja filozofskih ishodišta discipline. ${ }^{39}$

\footnotetext{
36 Vidi. Dodig Crnković, G.; W. Hofkhirchner. Floridi's „Open problems in Philosophy of information": ten years later. // Information 2, 2(2011), 327-359.

37 Floridi, L. What. Nav. dj., str. 141.

38 Hofkirchner, W. How to design the infosphere: the fourth revolution, the management of the life cycle of information, and information ethics as a macroethics. // Knowledge, Technology \& Policy 23, 1(2010), str. 178.

39 Bawden, D. Smoother pebbles and the shoulders of giants: the developing foundations of information science. // Journal of Information Science 34, 4(2008), str. 419.
} 
Iznimku čini Luciano Floridi, koji smatra da njegova filozofija informacije može pružiti knjižničnoj i informacijskoj znanost teorijsko-filozofski okvir unutar kojega će definirati svoju svrhu i ciljeve. Da je veza između te discipline i filozofije sasvim prirodna i logična, Floridi potvrđuje svojom izjavom u kojoj ističe da su one često povezane zbog istih razina, djelokruga i tema istraživanja te zato što dijele zajedničku metateorijsku razinu istraživanja. ${ }^{40}$

Sličan stav o obilježju knjižnične i informacijske znanosti kao metaznanosti jer se one, kao i filozofija, bave enciklopedijskim obuhvatom, možemo pronaći i kod Hjørlanda. No on u svojoj društveno-kognitivnoj (spoznajnoj) analizi povezuje knjižničnu i informacijsku znanost $s$ epistemologijom na način da ih smatra nekom vrstom primijenjene epistemologije, a pitanja poput toga što je znanje i kako ga prenosimo smatra ključnim epistemološkim pitanjima. ${ }^{41}$

Za Floridija knjižnična i informacijska znanost ima normativnu ulogu jer je knjižnica mjesto gdje se edukacijske i komunikacijske potrebe i vrijednosti provode, njeguju i potiču, gdje se sadržaj procjenjuje i odabire za korisnike. Knjižnična i informacijska znanost povezana je sa socijalnom epistemologijom budući da s njom dijeli interes za društvenu dinamiku svojih objekata, ima širok pristup te je empirijski orijentirana, no ona joj ne može pružiti zadovoljavajući teorijski okvir budući da knjižnična i informacijska znanost radi na višoj razini i njezin objekt nije znanje kao takvo, već informacijski izvori koji omogućavaju to znanje, makar i na neizravan način. ${ }^{42}$ Dakle osim što je knjižnična i informacijska znanost šire područje nego što je to epistemologija, prema Floridiju jedna od ključnih razlika jest to što je socijalna epistemologija više orijentirana na znanje nego na informaciju, pa samim time predlaže da bi bilo bolje kada bi knjižnična i informacijska znanost svoje teorijsko utemeljenje tražila unutar jedne veće discipline kao što je opća filozofija informacije.

Ideju o knjižničnoj i informacijskoj znanosti kao primijenjenoj filozofiji informacije Floridi je prvi put prezentirao 2002. godine u časopisu Social epistemology, u članku pod nazivom On defining library and information science as applied philosophy of information.

Analizirajući taj Floridijev članak Bawden i Robinson pronalaze u njemu tri ključne značajke. Prvo, knjižnična i informacijska znanost treba filozofiju za svoje teorijsko utemeljenje; drugo, socijalna epistemologija ne može pružiti zadovoljavajuće teorijsko uporište, dok filozofija informacija to može i treće, prihvaćanjem filozofije informacije kao svojeg teorijskog okvira unutar kojeg djeluje, knjižnična i informacijska znanost istraživanjem svog područja pridonosit će i razvoju same filozofije informacije. ${ }^{43}$

40 Floridi, L. On defining. Nav. dj., str. 38.

${ }^{41}$ Hjørland, B. Epistemology. Nav. dj., str. 257-270.

42 Floridi, L. On defining. Nav. dj., str. 39; 41.

43 Bawden, D.; L. Robinson. Curating. Nav. dj., str. 2. 
Prema Floridiju knjižnična i informacijska znanost zapravo je primijenjena disciplina filozofije informacije koja se bavi dokumentima, njihovim životnim ciklusom te postupcima, tehnikama i pomagalima kojima su dokumenti stvarani, kojima se njima upravlja i koji ih reguliraju. Ona zapravo primjenjuje temeljna načela i opće metode filozofije informacije u rješavanju određenih konkretnih problema te se isto tako bavi određenim specifičnim fenomenima. Knjižnična i informacijska znanost provodi empirijska istraživanja radi postizanja praktičnih ciljeva orijentiranih na usluge (npr. pohrana, procjena, obrazovanje, istraživanje, komunikacija i suradnja) te tako pridonosi razvoju temeljnih istraživanja filozofije informacije. ${ }^{44}$

Kao podloga za takvo razmišljanje Floridiju je poslužio članak K. R. Herolda pod nazivom Librarianship and the Philosophy of Information u kojem on veliku pažnju posvećuje odnosu između filozofije informacije i knjižničarstva. Prema njemu knjižničarstvo ima jedinstven status među ostalim disciplinama te bi trebalo energično pridonositi razvoju filozofije informacije i možda pronaći svoj identitet u obliku primijenjene filozofije informacije. Herold ne vjeruje da će ta nova filozofska ,stvar" zvana informacija na neki način nadvladati važnost knjiga, tiskanog znanja, glazbe ili zvuka i druge stvarnosti, ali priznaje da novo informacijsko doba donosi niz suptilnih promjena u načinu na koji mislimo da dijelimo svoja iskustva i zato moramo biti aktivni sudionici u raspravi o filozofiji informacije. ${ }^{45}$

Kao jedan od argumenta za prihvaćanje filozofije informacije kao novog teorijskog utočišta za knjižničnu i informacijsku znanost, Floridi ističe kako već postoje brojne informacijsko-teorijske i računalne metodologije koje je filozofija razvila i primjenjuje ih u raznim filozofskim područjima, i to kako bi:

- proširila razumijevanje kognitivnih i lingvističkih sposobnosti ljudi i životinja i mogućnosti formi umjetne inteligencije (filozofija umjetne inteligencije, informacijsko-teorijska semantika, informacijsko-teorijska epistemologija, dinamična semantika)

- analizirala inferencijalne i računalne procese (filozofija računalstva, filozofija računalne znanosti, logika informacijskog tijeka, situacijska logika)

- objasnila organizacijska načela života i agenata (filozofija umjetnog života, kibernetika i filozofija robota, teorija igre i odluke)

- izumila nove pristupe modeliranju fizičkih i konceptualnih sustava (formalna ontologija, teorija informacijskih sustava, filozofija virtualne stvarnosti)

- oblikovala metodologiju znanstvenog znanja (filozofija znanosti, računalne metodologije filozofije znanosti)

44 Floridi, L. On defining. Nav. dj., str. 46.

45 Herold, K. R. Librarianship and the philosophy of information. // Library Philosophy and Practice 3, 2(2001), str. 11. 
- istražila etičke probleme (računalna i informacijska pismenost, etika umjetne inteligencije), pitanja estetike (teorija digitalne multimedije, teorija hiperteksta i književni kriticizam) te filozofske, antropološke i društvene fenomene koje karakterizira informacijsko društvo i ponašanja ljudi u digitalnoj okolini (kiberfilozofija) ${ }^{46}$

U pokušaju da dodatno objasni zašto filozofija informacije može bolje odgovoriti na temeljna filozofska pitanja iz domene knjižnične i informacijske znanosti nego što je to činila socijalna epistemologija, Floridi ističe da je najznačajnija veza između knjižnične i informacijske znaosti i filozofije informacije stav po kojem se informacija nalazi u prijelaznom događaju između eksternalističkog i internalističkog pristupa definiranju informacije. Prema njemu je informacija, kao i semantika općenito, jedna od onih dvodimenzionalnih stvari koje nisu ni ovdje ni ondje, već na razmeđi između nas i okoline, poput praga (engl. treshold) između dvaju prostora. Ona je relacijski fenomen. Liminalni koncept informacije ne može se svesti na neki oblik eksternalizma (naturalizacija informacije) ili internalizma (informacije u mislima pojedinca). Floridi ne prihvaća ni jedno ni drugo, već za sebe kaže da je ,iliminalist“, odnosno „ontološki amfibijalan“. Taj prijelazni događaj u kojem nastaje informacija, dakle između zabilježenog znanja i recepcije tog znanja, razvija cjelovit informacijski proces, a njegovim praktičnim aspektom bavi se knjižnična i informacijska znanost $i$ to je jedan od razloga zbog kojih ih Floridi vidi kao primijenjenu filozofiju informacije. ${ }^{47}$

Na značajniji odjek u literaturi iz knjižnične i informacijske znanosti naišla je Floridijeva ideja „upravljanja semantičkim okruženjem“ (engl. stewardship of the semantic environment), kojom bi knjižnična i informacijska znanost zauzela ključnu poziciju u filozofiji informacije. ${ }^{48}$ Ideja o upravljanju semantičkim okruženjem usidrena je u kritici socijalne epistemologije. Naime knjižničarska praksa izgradnje zbirki ne počiva na ideji ,istinitosti“ zbirki u najužem smislu. Knjižnična i informacijska znanost bavi se smislenim podacima, tj. semantičkim sadržajem koji se sastoji od podataka koji su oblikovani i smisleni, a cijela disciplina pritom je fokusirana na upravljanje takvim semantičkim okruženjima. ${ }^{49}$

Nakon što je Floridi iznio svoju ideju o promjeni paradigme teorijskog utemeljenja knjižnične i informacijske znanosti, njegov je rad naišao na podijeljene reakcije znanstvenika. U nastavku rada ukratko ćemo spomenuti neke autore koji su kritizirali Floridijevu ideju o knjižničnoj i informacijskoj znanosti kao primijenjenoj filozofiji informacije, kao i one koji zagovaraju takvu ideju.

\footnotetext{
46 Floridi, L. On defining. Nav. dj., str. 45.

47 Floridi, L. Afterword. LIS as applied philosophy of information: a reappraisal. // Library Trends 53, 3(2004), str. 661-662.

48 Isto, str. 658-685.

49 Van der Veer Martens, B. New grounds for ontic trust: information objects and LIS. // Education for Information 33, 1(2017), str. 42.
} 


\subsubsection{Kritički pristup}

Jednu od poznatijih kritika Floridijeve filozofije informacije iznio je I. Cornelius u svom članku pod nazivnom Information and its Philosophy, u kojem ističe da Floridi nije svjestan društvene prirode knjižnične i informacijske znanosti te kritizira njegovo razumijevanje informacija kao jednostavnog sustava za prijenos podataka. On tvrdi da Floridi nema osjećaja za društveni kontekst informacija i tako degradira socijalnu epistemologiju budući da informacije ne mogu imati bilo kakvo objektivno značenje koje bi bilo nezavisno od korisnika. I. Cornelius zamjera mu i to što ne uzima u obzir činjenicu pluralizma knjižnične i informacijske znanosti te naglašava da je za njega Floridi samo ideolog jedne interesne skupine koja je usmjerena isključivo na istraživanja, a ne na onu najbrojniju skupinu koja obavlja praktični rad. Pomalo ironično ističe da su se knjižničari prvo morali preoblikovati u informacijske znanstvenike, zatim u informacijske menadžere, a sada bi prema Floridiju trebali postati i informacijski filozofi. Ipak u svom radu Cornelius priznaje da knjižnična i informacijska znanost mogu imati koristi od filozofije informacije, no da bi ta filozofija mogla biti u hijerarhijskom odnosu, morala bi pružiti više nego što je to Floridi uspio prikazati. ${ }^{50}$

Kao zaključak Cornelius navodi kako je opravdano Floridijevo traganje za teorijskim utemeljenjem discipline, no ono bi trebalo posjedovati empirijski senzibilitet koji će uzeti u obzir odnos između svrhe, prakse i društvenog konteksta informacija. Ono što nam zapravo treba jest „filozofija informacije $2 “{ }^{51}$

U svom odgovoru I. Corneliusu, ali i ostalim autorima koji smatraju kako filozofija informacije nije dovoljno društvena da bi poslužila za teorijsko uporište knjižničnoj i informacijskoj znanost, Floridi ističe da postoje tri razine na kojima se može primijeniti filozofija informacije. Prva je ona rutinska, koja je vidljiva u svakodnevnoj knjižničnoj praksi; druga razina obuhvaća opisivanje znanja u disciplini, kao primjerice u obrazovnim programima knjižničara, a treća, za koju se zapravo zanima malen broj ljudi, bavi se teorijskim proučavanjem temeljnih postavki. Filozofija informacije odnosi se upravo na tu treću razinu, ali potencijalno potiče i razvoj teorija u prvim dvjema. ${ }^{52}$

Od važnijih kritika svakako treba spomenuti D. Fallisa i njegov članak iz 2004. godine pod naslovom On Verifying the accuracy of Information: Philosophical Perspectives, u kojem govori o korisnosti filozofije informacije u procjeni točnosti informacija. Naime to pitanje o točnosti zabilježenih podataka za njega je, kao i za Floridija, jedno od najvažnijih pitanja, u čijem rješavanju puno više može pomoći epistemologija svjedočanstva Davida Huma i Alvina Goldmana jer se bavi propitivanjem točnosti svjedočanstva kao izvora znanja. ${ }^{53}$

s0 Cornelius, I. Information and Its Philosophy. // Library Trends 53, 3(2004), str. 382.

51 Isto, str. 386.

52 Floridi, L. Afterword. Nav.dj., str. 658-659.

53 Fallis, D. On verifying the accuracy of information: philosophical perspectives. // Library Trends 52, 3(2004), 463-487. 
Interesantno je i kritičko promišljanje o filozofiji informacije koje iznosi B. Frohmann. On smatra da se filozofija informacije zapravo temelji na filozofiji dokumentacije, odnosno dokumentalistici, te da joj je podređena. Prema njegovu mišljenju nema potrebe za nekom novom, ontološki utemeljenom filozofijom, kad odgovore ionako već možemo pronaći u filozofiji dokumentacije. Neki znanstvenici, poput Floridija, ističu da je razvoj filozofije informacije posebno važan danas, u digitalno doba, s čime se Frohmann ne slaže tvrdeći da digitalni oblik suvremenih dokumenata ne stvara posebne filozofske imperative s kojima se dokumentalistika ne bi mogla nositi. ${ }^{54}$

\subsubsection{Afirmativni pristup}

Zanimljiva je činjenica koju ističe i J. Furner ${ }^{55}$, a prema kojoj u literaturi koja se bavi knjižničnom i informacijskom znanošću ne nalazimo previše tekstova ni o Floridiju ni o filozofiji informacije. Slično razmišlja i B. Van der Veer Martens kada kaže da je u posljednjih osamdeset godina nastao popriličan broj kvalitetnih radova koji su se bavili odnosom između knjižnične i informacijske znanosti i filozofije, ali, zanimljivo, oni nisu privukli preveliku pažnju izvan polja. Nasuprot tomu, Floridijevi radovi izazvali su veću pažnju izvan knjižnične i informacijske znanosti, iako se čini da je to područje idealno za prakticiranje filozofije informacije. ${ }^{56}$

Veći broj analitičkih tekstova koji pažnju posvećuju odnosu između filozofije informacije i knjižnične i informacijske znanosti objavljen je u tematskom broju časopisa Library Trends iz 2015. godine. ${ }^{57}$ Posebno je zanimljiv značajan broj članaka koji prihvaćaju ideju filozofije informacije kao discipline unutar koje knjižnična i informacijska znanost pronalaze svoje utemeljenje. Spomenimo rad J. D. Dinneena i C. Braunera ${ }^{58}$ u kojem autori prikazuju kako su entiteti i događaji koji zauzimaju središnju ulogu u informacijskoj znanosti bolje opisani u filozofiji informacije nego u nekim drugim teorijama te rad u kojem B. Van der Veer Martens ${ }^{59}$ daje prvu detaljnu analizu vrijednosti filozofije informacije sa stajališta knjižnične i informacijske znanosti.

Ako promatramo znanstvene radove nastale u posljednje dvije godine, možemo zaključiti da je sve veći broj autora koji prihvaćaju filozofiju informacije kao rele-

\footnotetext{
54 Frohmann, B. Documentation redux : prolegomenon to (another) philosophy of information. // Library Trends 52, 3(2004), str. 406.

55 Furner, J. Nav. dj., str. 9.

56 Van der Veer Martens, B. An illustrated introduction to the infosphere. // Library Trends 63, 3(2015), str. 320.

57 Library Trends 63, 3(2015).

58 Dinneen, J.D.; C. Brauner. Practical and philosophical considerations for defining information as well-formed, meaningful data in the information sciences. // Library Trends 63, 3(2015), str. $378-400$.

59 Van der Veer Martens, B. An illustrated. Nav.dj., str. 217-361.
} 
vantnu znanstvenu disciplinu te u njoj pronalaze i mjesto za knjižničnu i informacijsku znanost. Neki autori već su ranije prihvatili ideju knjižnične i informacijske znanosti kao primijenjene filozofije informacije. Primjerice A. Spink i C. Cole ${ }^{60} \mathrm{u}$ svom članku iz 2004. godine pod naslovom A Human Information Behavior approach to a Philosophy of information pozitivno gledaju na filozofiju informacije te zagovaraju potrebu za sinergijom između filozofije informacije i informacijskog ponašanja definiranog kao ukupnost ljudskog ponašanja u odnosu na informacijske izvore i kanale.

Temeljitu analizu potrebe utemeljenja glavnih domena znanja knjižnične i informacijske znanosti (pretraživanja informacija, upravljanja informacijama i znanjem, organizacije informacija, bibliometrije, informacijskog ponašanja i informacijske pismenosti) u filozofiji informacije provela je T. Tomic zaključujući da filozofija informacije može funkcionirati kao metateorija svake od analiziranih domena informacijske znanosti. ${ }^{61}$

Opširno i relevantno obrazloženje za konceptualno utemeljenje knjižnične i informacijske znanosti u filozofiji informacija ponudio je R. Fyffe pozivajući se na Floridijevu ideju ,upravljanja semantičkim okruženjem“", koja je ključna u definiranju normativnosti polja, primjerice u kontekstu upravljanja životnim ciklusom informacijskih izvora ili informacijskom opismenjivanju. ${ }^{62}$ Fyffe nadalje ističe da su knjižnice tradicionalno fokusirane na odabir, nabavu, organizaciju, pohranu i korištenje objavljenih informacija, no manje su uključene u proces stvaranja koji prethodi objavljivanju ili ponovnom korištenju. Digitalne tehnologije bešavno integriraju takve procese i otvaraju nove funkcije za knjižničare, poput suradnje u ranoj fazi stvaranja izvora kako bi se primjerice osiguralo korištenje primjerenih standarda ili formata radi dugoročne uporabljivosti ili odabir strategija objavljivanja s obzirom na različite modalitete zaštite autorskih prava i sl. ${ }^{63}$

Recentni afirmativan osvrt na filozofiju informacije upućuje na podudarnost koncepta infosfere i GLAM-sektora (engl. Galleries, Libraries, Archives, Museums), tj. baštinskih ustanova, među kojima digitalno okruženje briše granice i potiče njihovu konvergenciju. ${ }^{64}$ Floridijeva infosfera također primjereno opisuje proširenu sferu interesa knjižnica, koje se više ne ograničavaju na tradicionalnu funkciju pružanja pristupa ili zaštite lokalnih tiskanih zbirki, nego organiziraju i omogućuju pristup i pretraživanje raznorodnim digitalnim dokumentima, prikupljajući, čuvajući i obrađujući nove tipove podataka i omogućujući evoluciju potrošača informacija u stvaratelja i kritičara informacija.

\footnotetext{
60 Spink, A.; C. Cole. A human information behavior approach to a philosophy of information. // Library Trends 52, 3(2004), 617-628.

61 Tomić, T. The philosophy of information as an underlying and unifying theory of information science. // Information Research: An International Electronic Journal 15, 4(2010), 1-13.

62 Fyffe, R. Nav. dj., str. 268.

63 Isto, str. 274.

64 Van der Veer Martens, B. New grounds. Nav. dj., str. 37; 54.
} 
Općenito gledajući, Floridijeva filozofija informacije samo se jednim dijelom osvrnula na knjižničarstvo, kao i na knjižničnu i informacijsku znanost, te je stoga, iako je prošlo dosta godina od ideje o knjižničnoj i informacijskoj znanosti kao primijenjenoj filozofiji informacije, tek tijekom posljednjih nekoliko godina naišla na odjek u knjižničarskim krugovima. Neki su od mogućih razloga za sporu recepciju i to što su stručnjaci iz polja knjižnične i informacijske znanosti više orijentirani na praktična nego na teorijska promišljanja o svojoj struci, zatim činjenica da se većina literature koja problematizira tu temu nalazi u filozofskim časopisima i, konačno, nepovjerenje prema filozofiji informacije kao novoj samostalnoj znanstvenoj disciplini. U svakom slučaju, knjižničari ne bi smjeli ostati ravnodušni na takva teorijska promišljanja o samoj biti svoje profesije, već bi trebali postati njihovi aktivni sudionici.

\section{Zaključak}

Potraga za intelektualnim filozofskim temeljima odredila je razvoj knjižnične i informacijske znanosti kao znanstvene discipline od njezinih početaka, no potpuni konsenzus u vidu općeprihvaćenog teorijsko-filozofskog uporišta do danas nije postignut. Nepostojanje eksplicitnih filozofskih premisa nesumnjivo je utjecalo na status knjižnične i informacijske znanosti kao „slabe“ znanstvene discipline i pridonijelo razvoju krize identiteta, dok su dinamika razvoja, umreženost i složenost digitalnih okruženja dodatno zaoštrili pitanja znanstvene pozicije te discipline. Dominantno digitalno okruženje iznjedrilo je nova pitanja i zaoštrilo probleme prvo na praktičnoj, a potom i na teorijskoj i etičkoj razini, s kojima su se cjelovitije uhvatili ukoštac tek malobrojni mislioci, a među njima svakako treba istaknuti Luciana Floridija i njegovu filozofiju informacije. U radu je provedena kritička analiza konceptualnog opsega i potencijalnog dosega filozofije informacije kao uporišta knjižnične i informacijske znanosti. Iako Floridijeva ideja u početku nije bila posebno dobro prihvaćena, u radu smo nastojali pokazati da se u zadnje vrijeme javlja sve veći broj autora koji u svojim radovima vide knjižničnu i informacijsku znanost kao primijenjenu filozofiju informacije. Tomu su zacijelo pridonijeli mnogi problemski aspekti discipline koji su sve uočljiviji u digitalnom okruženju, a koji zrcale obilježja Floridijeve infosfere i njegov koncept upravljanja semantičkim okruženjem kao ključnim fokusom knjižnične i informacijske znanosti. Floridijeva semantička teorija informacija, u kojoj je informacija shvaćena kao dobro organiziran, smislen i istinit podatak, predstavlja značajan doprinos teorijskom promišljanju o informaciji i njezinoj ulozi unutar knjižnične i informacijske znanosti; njegova interpretacija na razini podatka, koju su neki autori, poput Corneliusa, isticali kao slabost filozofije informacija, u žarište discipline pravovremeno postavlja problem velikih podataka (engl. big data) i posljedične etičke probleme. Kako bismo preciznije elaborirali obilježja i potencijal filozofije informacije, 
osvrnuli smo se na problematičnost i nedostatnost uvriježenih pristupa filozofskog utemeljenja u Popperovoj teoriji o tri svijeta ili u socijalnoj epistemologiji, koje kao teorijski okviri unutar kojih bi se smjestila knjižnična i informacijska znanost pokazuju znatne manjkavosti.

U razmatranju potencijala Floridijeve filozofije informacije u ovome smo radu krenuli od konstatacije o skromnim filozofskim premisama knjižnične i informacijske znanosti kao uzroku učestalog propitivanja znanstvene snage i identiteta discipline. Ozbiljan kandidat za popunjavanje tog praznog prostora sasvim je sigurno filozofija informacije čije vezivno tkivo - ideja infosfere, semantička teorija informacija, upravljanje semantičkim okruženjima i etička promišljanja - definira i konceptualni prostor knjižnične i informacijske znanosti u digitalnom dobu. Štoviše, držimo da filozofija informacije nudi potencijal za znanstveno osnaživanje knjižnične i informacijske znanosti koja bi kao primijenjena filozofija informacije aktivno pridonosila analizi i suoblikovanju infosfere, umjesto posuđivanja teorije drugih područja. Floridi kao alternativu predlaže filozofiju informacije, i to zato jer smatra da knjižnična i informacijska znanost zapravo primjenjuje temeljna načela i metode filozofije informacije u rješavanju određenih konkretnih problema, a provedena analiza radova iz šireg područja informacijskih znanosti pokazala je kako su i ontološka i empirijska pitanja koja je Floridi obrađivao u samoj srži njihova zanimanja, što filozofiju informacije čini produktivnim kandidatom za intelektualni i filozofski temelj te discipline.

\section{LITERATURA}

Aparac-Gazivoda, T. Teorijske osnove knjižnične znanosti. Zagreb : Zavod za informacijske studije, 1993.

Aparac-Jelušić, T.; F. Ibekwe-SanJuan; I. Huvila; L. Ma; V.O.-R. Jimenez; J. Warner. Crossing the boundaries in information science : perspectives on interdisciplinarity. // Proceedings of the Association for Information Science and Technology 50, 1(2013), 1-3.

Aristotel. Metafizika. Zagreb : Globus, 1988.

Bawden, D. Smoother pebbles and the shoulders of giants: the developing foundations of information science. // Journal of Information Science 34, 4(2008), 415-426.

Bawden, D. The three worlds of health information. // Journal of Information Science 28, 1(2002), 51-62.

Bawden, D.; L. Robinson. Curating the infosphere: Luciano Floridi's philosophy of information as the foundation for library and information science. // Journal of Documentation 73, 5(2017), 1-20. 
Bawden, D.; L. Robinson. Super-Science, fundamental dimension, way of being : library and information science in an age of messages. // Information Cultures in the Digital Age / ed. by M. Kelly and J. Bielby. Wiesbaden : Springer VS, 2016. Str. 31-43.

Brookes, B.C. The foundations of information science: Part I. : Philosophical aspects. // Journal of Information Science 2, 3-4(1980), 125-133.

Capurro, R. What is information science for? : a philosophical reflection. // Conceptions of library and information science : historical, empirical and theoretical perspectives / ed. by Pertti Vakkari and Blaise Cronin. London : Taylor Graham, 1992. Str. 82-96.

Chow, A. S.; T. L. Shaw; D. Gwynn; D. Martensen; M. Howard. Changing times and requirements: implications for LIS education. // LIBRES: Library \& Information Science Research Electronic Journal 21,1(2011). [citirano: 2018-04-15]. Dostupno na: https://libres.uncg.edu/ir/uncg/f/A_Chow_Changing_2011.pdf.

Cornelius, I. Information and its philosophy. // Library Trends 53, 3(2004), 377-386.

Cronin, B. The waxing and waning of a field : reflections on information studies education. // Information Research 17, 3(2012), paper 529. [citirano: 2018-04-15]. Dostupno na: http://nformationR.net/ir/17-3/paper529.html.

Dillon, A. Keynote address: library and information science as a research domain: problems and prospects. // Information Research 12, 4(2007), 1-8.

Dillon, A. What it means to be an iSchool. // Journal of Education for Library and Information Science 53,4(2012), 267-273.

Dinneen, J.D.; C. Brauner. Practical and philosophical considerations for defining information as well-formed, meaningful data in the information sciences. // Library Trends 63, 3(2015), 378-400.

Dodig Crnković, G.; W. Hofkhirchner. Floridi’s „Open Problems in Philosophy of Information": ten years later. // Information 2, 2(2011), 327-359.

Fallis, D. On verifying the accuracy of information: philosophical perspectives. // Library Trends 52, 3(2004), 463-487.

Feather, J. LIS research in the United Kingdom : reflections and prospects. // Journal of Librarianship and Information Science 41, 3(2010), 173-181.

Floridi, L. Afterword. LIS as applied philosophy of information: a reappraisal. // Library Trends 53, 3(2004), 658-685.

Floridi, L. On defining library and information science as applied philosophy of information. // Social Epistemology 16, 1(2002), 37-49.

Floridi, L. The philosophy of information. Oxford : Oxford University Press, 2011.

Floridi, L. What is the philosophy of information? // Metaphilosophy 33, 1-2(2002), $123-145$.

Ford, E. What do we do and why do we do it? // In the Library with the Lead Pipe, (2012). [citirano: 2017-12-20]. Dostupno na: http://inthelibrarywiththeleadpipe. org/2012/what-do-we-do-and-why-do-we-do-it/.

Frohmann, B. Documentation redux : prolegomenon to (another) philosophy of information. // Library Trends 52, 3(2004), 387-407. 
Furner, J. Philosophy and information studies. // Annual Review of Information Science and Technology 44 (2008), 161-200.

Fyffe, R. The value of information : normativity, epistemology, and LIS in Luciano Floridi. // portal: Libraries and the Academy 15, 2(2015), 267-286.

Herold, K. R. Librarianship and the philosophy of information. // Library Philosophy and Practice 3, 2(2001), 1-16.

Hjørland, B. Epistemology and the socio-cognitive perspective in information science. // Journal of the American Society for Information Science and Technology 53, $4(2002), 257-270$.

Hjørland, B. Information science and its core concepts : levels of disagreement. // Theories of information, communication and knowledge / ed. by Fidelia Ibekwe-SanJuan and Thomas M. Dousa. Dordrecht : Springer, 2014. Str. 205-235.

Hofkirchner, W. How to design the infosphere: the fourth revolution, the management of the life cycle of information, and information ethics as a macroethics. // Knowledge, Technology \& Policy 23, 1(2010), 177-192.

Horić, A. Informacija - povijest jednog pojma: o Capurrovom razumijevanju pojma informacije. // Vjesnik bibliotekara Hrvatske 50, 1/2(2007), 96-106.

Jarvelin, K. ; P. Vakkari. Content analysis of research articles in library and information science. // Library and Information Science Research 12, 4(1990), 395- 421.

Lorenz, M. ; A. Novaka. The i-School phenomenon: history and present situation. // Revue of Librarianship 25, 2(2014), 58-82. [citirano: 2017-12-20]. Dostupno na: http://full.nkp.cz/nkkr/knihovna142_suppl/142supp058.htm.

Pettigrew, K. E. ; L. Mckechnie. The use of theory in information science research. // Journal of the Association for Information Science and Technology 52, 1(2001), $62-73$.

Pierce, S. Dead Germans and the theory of librarianship. // American Libraries 23 8(1992), 641-643.

Popper, K. R. U potrazi za boljim svijetom: predavanja i napisi iz trideset godina. Zagreb : KruZak, 1997.

Spink, A.; C. Cole. A human information behavior approach to a philosophy of information. // Library Trends 52, 3(2004), 617-628.

Tomic, T. The philosophy of information as an underlying and unifying theory of information science. // Information Research: An International Electronic Journal 15, $4(2010), 1-13$.

Tuđman, M. Teorija informacijske znanosti. Zagreb: Hrvatska sveučilišna naknada : Nacionalna i sveučilišna knjižnica, 2014.

Van der Veer Martens, B. An illustrated introduction to the infosphere. // Library Trands 63, 3(2015), 217-361.

Van der Veer Martens, B. New grounds for ontic trust : information objects and LIS. // Education for Information 33, 1(2017), 37-54.

Zwadlo, J. We don't need philosophy of library and information science : we're confused enough already. // The Library Quarterly 67, 2(1997), 103-121. 